\title{
MASTERY OF CONCEPTS, SCIENTIFIC ATTITUDES, AND SCIENCE PROCESS SKILLS IN INQUIRY-BASED LEARNING IN THE $5^{\text {th }}$ GRADE
}

\author{
Tri Suryaningsih') ${ }^{1)}$ Ferry Ferdiana Ruslih ${ }^{2}$ \\ Universitas Islam Negeri (UIN) Syarif Hidayatullah'), SDN Gandaria Utara 03 Jakarta \\ Selatan $\left.{ }^{2}\right)$ \\ E-mail: tri.suryaningsih@,uinikt.ac.id ${ }^{1}$, ferryqyonkz@gmail.com¹) \\ Submit: 10 Juni 2020, Revisi: 20 Juli 2020, Approve: 11 November 2020
}

\begin{abstract}
The purpose of this study is to analyze the improvement mastery a concept, scientific attitude, and science process skill in the learning of structured and guided inquiry learning and analyzed the difference. This research was conducted in SDN Purwoyoso 02 and 03 with the quasyexperiment method, experiment class 1 using structured inquiry and exeperiment class 2 using guided inquiry learning model. Data analysis techniques use $\mathrm{N}$-gain and independent samples t-test. The study showed the following results: (1) there is an increased of mastery of concepts, scientific attitudes and scientific process skills students in structured inquiry class with medium category gain. (2) there is an increase of mastery of concepts, scientific attitudes with and science process skills students in guided inquiry class with medium category gain. (3) there is a difference of mastery of concept, scientific attitude and science process skill between structured and guided inquiry class students. The result of mastery of scientific concepts, scientific attitudes, and inquiry skills of inquiry classes is higher than the structured inquiry class. The results of this study can be concluded that inquiry learning is better guided than structured inquiry.
\end{abstract}

Keywords: Mastery of Concepts, Scientific Attitude, Science Process Skills, Structured Inquiry, Guided Inquiry.

Pengutipan: Tri Suryaningsih \& Ferry Ferdiana Ruslih. (2020). Mastery of Concepts, Scientific Attitudes, and Science Process Skills in Inquiry-Based Learning in the 5th Grade. JMIE: Journal of Madrasah Ibtidaiyah Education, 4(2), 2020, 248-260. jmie.v4i2.191.

Permalink/DOI: http:/ /dx.doi.org/10.32934/jmie.v4i2.191 



\section{INTRODUCTION}

The most important goal of science education is to teach students how to become involved in the investigation and allow individuals to use science process skills (Aktamis, H., \& Ergin, 2008). In the step of science investigation activities available space for teachers to develop a scientific attitude (Hendracipta, 2016). By studying science students are expected to have knowledge, attitudes, skills, ideas and concepts that are organized about the natural environment more deeply, gained from experience through a series of scientific inquiry process.

Developing a school curriculum is crucial to improving the science process skills, improving science process skills in science education are still a problem in the school curriculum (Ergul, R., Simsekli, Y., Calis, S., Ozdilek, Z., Gocmencelebi, S., \& Sanli, 2011). Studies around the world have revealed an important issue of increasing the percentage of students who are not interested in science. Many students, especially women, have negative feelings and attitudes toward science, which prevent them from continuing with scientific inquiry (Hacieminoglu, 2016). From the study, the idea that traditional teaching and more reliance on textbooks could be responsible for the increase in students' negative attitudes about science (Hacieminoglu et al, 2009) and teachers do not teach about science process skills first and do not encourage students to seek (Ergul, R., Simsekli, Y., Calis, S., Ozdilek, Z., Gocmencelebi, S., \& Sanli, 2011). This condition shows that science learning process in primary school is still done conventionally. The role of the teacher has not fully implemented the learning actively and creatively in involving the students and not yet using the approach/learning strategy that varies based on the character of the subject (Susanto, 2012).

The results of observations of science learning in Purwoyoso State Elementary School 02 and 03 Semarang in the second semester of 2016-2017 learning year, showed that in general students only listened to the subject matter and did the assignments given by the teacher. In the learning process students become passive and natural science learning becomes less optimal. When the teacher asks questions, most students are busy chatting with their friends, not paying attention to the teacher and some even look sleepy during the learning process. In the lecture process, the teacher has not been able to optimize the process skills and scientific attitude because students do not conduct scientific experiments. The scientific attitude that arises in this learning is only the aspect of curiosity by asking the teacher. In grade 5 SDN Purwoyoso 02 city of Semarang, of 64 students who asked the teacher only $21.9 \%$ or 14 students and in grade 5 SDN Purwoyoso 03 city of Semarang, out of 105 students who asked the teacher only $24.8 \%$ or 26 students. The science process skills that appear are only aspects of predicting answers to teacher questions based on student experience or based on books. In class 5 SDN Purwoyoso 02 city of Semarang, of 64 students who predicted answers to only $25 \%$ or 16 students and in grade 5 SDN Purwoyoso 03 city of Semarang, out of 105 students who predicted answers to only $27.6 \%$ or 29 students. Scientific attitudes and science process skills in conducting 
experiments have not yet been seen and cannot be measured optimally because learning is still dominated by teachers and much depends on textbooks. Things that occur in this learning are not in accordance with the learning objectives which include the development of the realm of attitudes, knowledge, and skills that are elaborated for each education unit (Permendikbud, 2016). Learning will be more meaningful when teachers invite students to discover concepts learned through scientific processes.

Inquiry is defined as a very effective teaching approach and method that helps students to understand concepts and use process skills (Ergul, R., Simsekli, Y., Calis, S., Ozdilek, Z., Gocmencelebi, S., \& Sanli, 2011). Each step of inquiry-based learning activities must contain elements of activities to foster scientific attitudes which include objective/honest, unhurried, open, not confusing facts with opinions, caution, investigative attitudes or high curiosity (Hendracipta, 2016). In inquiry-based learning, teachers are seen as learning facilitators and not a container of knowledge. Therefore the work of teachers in the inquiry environment is not to provide knowledge, but to assist students throughout the process of discovering their own knowledge (Aceska, 2016).

Inquiry learning has four categories: demonstration inquiry, structured inquiry, guided inquiry, and independent inquiry. Students at the elementary school level of the high class need a lot of guidance and direction because they are not accustomed to conducting inquiry learning so what primary schools can apply is structured inquiry and guided inquiry. Structured inquiry learning and guided inquiry have similarities in terms of involving students in the learning process so that they are able to develop students' cognitive, affective, and psychomotor (Sudaryanti, 2015). However, the two types of inquiry learning have differences in terms of teacher involvement in the learning process. With the difference in teacher involvement in the learning process it is possible that it will affect the learning outcomes obtained by students. On the other hand, the teacher does not have experience in comparing the two inquiry learning so empirical evidence is needed to prove which is better than the two inquiry learning.

Inquiry-based learning has several advantages. The advantages contained in inquiry learning are 1) developing cognitive, affective and psychomotor aspects in a balanced manner; 2) give space to students to learn according to their learning style; 3) in accordance with the development of modern psychology which considers learning to be a process of behavior change thanks to experience; and 4) can serve the needs of students above the average, meaning that students who have good learning abilities will not be hampered by students who are weak in learning (Sanjaya, 2009).

Besides having advantages, inquiry learning certainly has weaknesses or obstacles in its application. Barriers that can occur in carrying out inquiry learning include 1) lack of time; 2) confusion in conducting inquiry; and 3) little design in the given task. Some things teachers can 
do to overcome this are: 1) the group teaching approach; 2) using constructivism views in learning; and 3) increasing competence in designing and implementing inquiry (Kuhlthau, 2003).

To involve students in the learning process so as to be able to develop a variety of skills both mastery of concepts, scientific attitudes, and science process skills of students in science learning so that the desired learning outcomes have increased it requires structured and guided inquiry-based learning. After applying structured and guided inquiry-based learning, it is necessary to know which is better in improving students' mastery of concepts, scientific attitudes, and science process skills.

Based on the above problems, it can be formulated this research problem as follows: (1) How is the influence of mastery of concept, scientific attitude, and science process skill of grade V SD students in structured inquiry learning? (2) How does the influence of mastery of concept, scientific attitude, and science process skill of students in grade V SD in guided inquiry learning? (3) Is there a difference in the mastery of concepts, scientific attitude and science process skills among grade V SD students learning to use structured inquiry learning with guided inquiry learning?

\section{METHODS}

This research is quantitative in the form of experimental quasy with pretest-postest comparison group design. There were two class groups, the first experimental group using a structured inquiry learning model and a second experimental group using guided inquiry. The research was conducted in SDN Purwoyoso 02 and 03 with the population of all students of class V SDN Purwoyoso 02 and Purwoyoso 03 Ngaliyan district, Semarang city. Form of sampling using purposive sampling that is taking samples with certain consideration. The sample in this research is the students of VA SDN Purwoyoso 02 class of 31 students, VB class amounted to 33 students and students of VA SDN Purwoyoso 03 class amounted to 36 students, VB class amounted to 35 students. The total sample is 135 students.

Techniques for data collection in this study are as follows: (1) pre-test concept mastery before using structured and guided inquiry learning, (2) observing scientific attitudes and students' science process skills during the learning process taking place in the experimental class that uses structured and guided inquiry learning, (3) post-test mastery of concepts after using structured and guided inquiry learning.

Data collection instruments used in this study were tests and non-tests. The test used in the form of multiple choice questions mastered the concept of light material properties with 20 items that have been validated. Non-tests are used in the form of a scientific attitude observation sheet with five indicators namely curiosity, caution, honesty, persistence and openness. Observation sheet non-test science process skills with five indicators namely conducting experiments, observing, predicting, inferring and communicating. 


\section{RESULTS AND DISCUSSION}

\section{Mastery of Concepts}

Ability to master the concept of students obtained from pretest and post-test learning science. The results of concept mastering tests on structured and guided inquiry classes each gained significant improvement. Based on the pretest result, the structured and guided inquiry class is relatively the same. It is seen from the acquisition of master test results of student concepts before learning to use structured and guided inquiry. Postest results show differences, it is seen from the acquisition of test results after learning using structured and guided inquiry. The results of the concept of mastering the concept of structured and guided inquiry students are presented in graph 1.

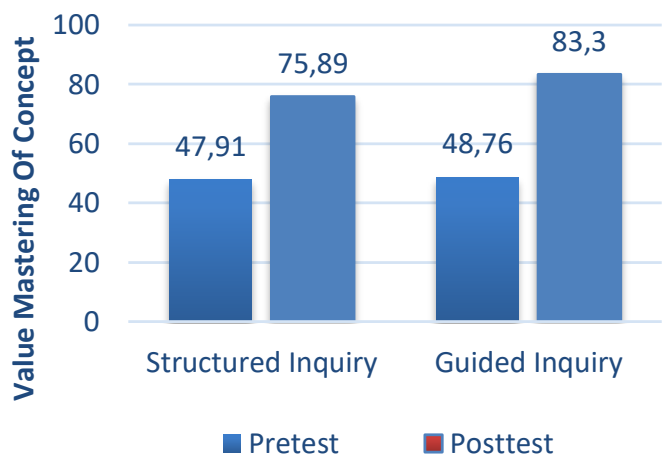

Graph 1. Results of Pretest and Posttest Mastery Concepts Structured and Guided Inquiry Classes

Based on the above table, the mastery of the concept of inquired structured and guided experienced a significant increase. This is because inquiry-based learning has a positive impact on conceptual understanding (Şimşek, P., \& Kabapınar, 2010), which involves a student centered process, students are given the opportunity to be actively involved in learning both mentally, intellectually, and socially emotional (Hermawati, 2012). As a subject of learning, students can optimize cognitive, affective, and psychomotor aspects equally (Sanjaya, 2009) through a process of inquiry and discovery. Investigation-based activities increase student motivation because inquiry gives students the freedom to make their choices, gives them the opportunity to make self-arrangements and to take part in it (Bayram, Z., Oskay, Ö. Ö., Erdem, E., Özgür, S. D., \& Şen, 2013). Inquiry-based learning can stimulate students 'motivation, apply student research skills, construct meaning and acquire scientific knowledge (Suduc, A. M., Bizoi, M., \& Gorghiu, 2015) so it has an impact on the mastery of student concepts.

The model of the study of mercury is very effective in improving the mastery of student concepts (Prasetyowati, E. N., \& Suyatno, 2016). This is supported by Budiman's research (2017) indicates that the improvement of conceptual mastery in inquiry model is greater than the increase of mastery in conventional learning model. Learning with guided inquiry 
experiments can improve the mastery of student concepts, this is because when doing the inquiry students can optimize the process of reconstruction of knowledge and understanding of a material (Praptiwi, L., Sarwi, \& Handayani, 2012).

Based on the pretest and posttest gain analysis the concept of structured inquiry class gets a gain value of 0.52 ; while the pretest and posttest gain analysis mastery of guided inquiry concept obtained a gain value of 0.68 . From each experimental class, the gain is in the medium category. Based on the results obtained post-test, there are differences in the average results of mastery of the concept of inquiry learning structured and guided, the following presented the results of differences test using independent samples t-test in table 1.

Table 1. Differentiated Test Mastery Concept of Structured and Guided Inquiry Classrooms

\begin{tabular}{|c|c|c|c|c|c|c|c|c|}
\hline & & \multicolumn{7}{|c|}{ t-test for Equality of Means } \\
\hline & & \multirow[t]{2}{*}{$\mathrm{T}$} & \multirow[t]{2}{*}{ Df } & \multirow[t]{2}{*}{$\begin{array}{l}\text { Sig. (2- } \\
\text { tailed) }\end{array}$} & \multirow[t]{2}{*}{$\begin{array}{c}\text { Mean } \\
\text { Differen } \\
\text { ce }\end{array}$} & \multirow{2}{*}{$\begin{array}{c}\text { Std. } \\
\text { Error } \\
\text { Differen } \\
\text { ce }\end{array}$} & \multicolumn{2}{|c|}{$\begin{array}{l}\text { 95\% Confidence } \\
\text { Interval of the } \\
\text { Difference }\end{array}$} \\
\hline & & & & & & & Lower & Upper \\
\hline \multirow{2}{*}{ PK } & $\begin{array}{c}\text { Equal } \\
\text { variances } \\
\text { assumed }\end{array}$ & $\begin{array}{c}- \\
4,308\end{array}$ & 134 &, 000 & $-7,438$ & 1,727 & $-10,853$ & $-4,023$ \\
\hline & $\begin{array}{c}\text { Equal } \\
\text { variances not } \\
\text { assumed }\end{array}$ & $\begin{array}{c}- \\
4,316\end{array}$ & $\begin{array}{c}132,61 \\
2\end{array}$ & ,000 & $-7,438$ & 1,723 & $-10,846$ & $-4,029$ \\
\hline
\end{tabular}

Based on the independent samples test t-test the mastery of the concept of structured inquired class and guided to obtain the level of significance $0.000<0.05$, then $\mathrm{H}_{0}$ rejected. This suggests that the mastery data of structured and guided inquiry class concepts has significant differences.

Structured inquiry learning, and guided inquiry, can both increase students' posttest scores in terms of mastery of concepts. However, the average mastery of the inquiry concept of the inquiry is higher than the structured inquiry class, because in guided inquiry, the teacher presents the question, the student investigates using the design/procedure chosen by the student (Bell et al 2005), the design/procedure in question namely methods and solutions so that students can independently determine the procedures they will use that impact on their involvement in finding the concepts learned. Whereas in structured inquiry learning students are involved in hands-on activity or laboratory work, collecting data, and drawing conclusions but referring to the steps teachers have made, which makes the students constrained by procedures that have been made so that students are less than optimal in finding the concepts learned. 
This is supported by Rahayu's research which states that there are significant differences in effectiveness on mastery of the concept of the classroom approach of guided inquiry and structured inquiry (Rahayu, 2016). The ability of mastery of the concept of guided inquiry class is higher than the structured inquiry class. Based on the test gain and independent samples ttest above, it can be concluded that the learning model structured inquiry and guided both can increase the mastery of the concept of students but have differences in improvement. Learning with inquiry is better guided in improving the mastery of student concepts rather than structured inquiry.

\section{Scientific Attitude}

The scientific attitude data is obtained from the observer observations made at each meeting in structured and guided inquiry learning. There are five indicators of scientific attitude that must be observed, namely curiosity, caution, diligence, honest and open. The observational data of scientific attitudes of each indicator are presented in table 2

Table 2. Results of Student's Scientific Attitudes Each Indicator

\begin{tabular}{cccccc}
\hline \multirow{2}{*}{ No } & \multirow{2}{*}{ Indicators } & \multicolumn{2}{c}{ Structured Inquiry } & \multicolumn{2}{c}{ Guided Inquiry } \\
\cline { 3 - 5 } & & Average (\%) & Annotation & Average (\%) & Annotation \\
\hline 1 & Curiosity & 74,25 & Good & 92,39 & Very Good \\
2 & Carefullness & 75,37 & Good & 84,05 & Very Good \\
3 & Perseverance & 75,00 & Good & 78,62 & Good \\
4 & Honesty & 75,00 & Good & 77,53 & Good \\
5 & Openness & 79,10 & Good & 77,17 & Good \\
\hline
\end{tabular}

Scientific attitudes in structured inquiry get well-categorized average on each indicator, whereas for guided scientific attitudes get a very good category average on curiosity and caution indicators, for other indicators to get a good category. This suggests that inquiry learning is structured and guided can make students' scientific attitude good. To see the improvement of scientific attitude, the following presented the scientific attitudes of each meeting in Table 3.

Table 3. Results of Scientific Attitudes of Structured s and Guided Inquiry Classes by Each Meeting

\begin{tabular}{|c|c|c|c|c|c|c|c|}
\hline \multirow{3}{*}{ No } & \multirow{3}{*}{ Classes } & \multicolumn{6}{|c|}{ Scientific attitudes } \\
\hline & & \multicolumn{6}{|c|}{ Average of Meetings (\%) } \\
\hline & & 1 st & $2^{\text {nd }}$ & $3^{\text {rd }}$ & $4^{\text {th }}$ & $5^{\text {th }}$ & $6^{\text {th }}$ \\
\hline 1 & Structured Inquiry & 47,98 & 53,73 & 57,61 & 64,55 & 72,46 & 75,74 \\
\hline 2 & Guided Inquiry & 49,56 & 55,86 & 60,00 & 68,04 & 75,14 & 81,95 \\
\hline
\end{tabular}


Based on the data in the table above, students' scientific attitude has increased at each meeting. scientific attitudes to structured and guided inquiry classes each have significant improvements, this is because students have high curiosity, can make decisions, develop a desire to seek answers, approach problems with open minds, practice problem-solving, objectives (Development, 2014), so students are not only studying a collection of knowledge in the form of facts, concepts or principles, but also studying the process of discovery itself in fostering a scientific attitude (Hendracipta, 2016).

This is supported by the results of research Uswatun and Rohaeti (2015: 148) showed that there is increasing scientific attitude of students on inquiry learning. Students who experience inquiry learning perform better than traditional methods and statistical analysis also shows that inquiry methods are effective for the development of scientific attitudes (Khan A, S., Shah, A., Makhdoom, S., Mahmood, Z., \& Zareen, 2012). Students can gain a more meaningful and stronger experience attached to their minds (Dewi, N. L., Dantes, N., \& Sadia, 2013) thereby positively impacting students' scientific attitudes.

Based on the gain analysis the scientific attitude of the structured inquiry class gained a gain of 0.55 ; while the scientific attitude of the guided inquiry class gained a gain of 0.64 . Structured and guided inquiry gain analysis uses the average value of scientific attitudes at first and sixth meetings. From both experiment classes, the gain is in the moderate category. Judging from the final result of scientific attitude, there is difference in the average result of scientific attitude of structured and guided inquiry study, the following is presented difference test result using independent samples t-test in table 3.

Table 4. Differentiated Test Scientific Attitudes of Structured and Guided Inquiry Classes

t-test for Equality of Means

\begin{tabular}{|c|c|c|c|c|c|c|c|c|}
\hline & \multirow[b]{5}{*}{$\mathrm{t}$} & \multirow[b]{5}{*}{$\mathrm{df}$} & \multirow{5}{*}{$\begin{array}{l}\text { Sig. (2- } \\
\text { tailed) }\end{array}$} & \multirow{5}{*}{$\begin{array}{c}\text { Mean } \\
\text { Differen } \\
\text { ce }\end{array}$} & \multirow{5}{*}{$\begin{array}{c}\text { Std. } \\
\text { Error } \\
\text { Differen } \\
\text { ce }\end{array}$} & \multirow{4}{*}{\multicolumn{2}{|c|}{$\begin{array}{c}95 \% \text { Confidence } \\
\text { Interval of the } \\
\text { Difference }\end{array}$}} \\
\hline & & & & & & & & \\
\hline & & & & & & & & \\
\hline & & & & & & & & \\
\hline & & & & & & & Lower & Upper \\
\hline \multirow{2}{*}{ SI } & Equal variances & $-3,490$ & 134 & ,001 & $-6,210$ & 1,779 & $-9,730$ & $-2,691$ \\
\hline & $\begin{array}{c}\text { Equal variances } \\
\text { not assumed }\end{array}$ & $-3,482$ & $\begin{array}{c}129,67 \\
3\end{array}$ & 001 & $-6,210$ & 1,784 & $-9,739$ & $-2,682$ \\
\hline
\end{tabular}

Based on the table above, it is obtained scientific attitude data at a significance level of $0.001<0.05$. This shows that there is a difference in scientific attitude between structured and guided inquiry classes. this is because in guided inquiry, the teacher presents the question, the 
student investigates using the design/procedure chosen by the student (Bell, R. L., Smetana, L., \& Binns, 2005), the design/procedure in question is the method and the solution so that the students can independently determine the procedures they will use that impact on their involvement in building a scientific attitude in their experiments. Whereas in structured inquiry learning students are involved in hands-on activity or laboratory work, collecting data, and drawing conclusions but referring to the steps teachers have made, which makes the students constrained by procedures that have been made so students are less than optimal in building a scientific attitude in their experiments.

This is supported by the research of Bunterm et. al (Bunterm, T., Lee, K., Ng Lan Kong, J., Srikoon, S., Vangpoomyai, P., Rattanavongsa, J., \& Rachahoon, 2014) that the scientific attitude in the structured inquiry group is still showing improvement. Students in guided inquiry groups showed greater improvement compared to structured inquiry groups. This is possible because students in guided inquiry groups have more opportunities to engage in the scientific process. Based on the gain test and the independent sample t-test, it can be concluded that the structured and joint guided inquiry learning model can improve students' scientific attitudes but have different improvements. Learning with inquiry is better structured in enhancing scientific attitude than structured inquiry.

\section{Science Process Skill}

Science process skills data were obtained from observer observations carried out at each meeting in structured and guided inquiry learning. There are five indicators of science process skills that should be observed: experiment, observation, prediction, conclusion and communication. Data on observations of the skills of the scientific process are presented in table 5

Table 5. Results of Student's Science Process Skills Each Indicator

\begin{tabular}{cccccc}
\hline \multirow{2}{*}{ No } & Indicators & \multicolumn{2}{c}{ Structured Inquiry } & \multicolumn{2}{c}{ Guided Inquiry } \\
\cline { 3 - 5 } & & Average (\%) & Annotation & Average (\%) & Annotation \\
\hline 1 & Experiment & 79,85 & Good & 82,97 & Very Good \\
2 & Observe & 82,08 & Very Good & 81,88 & Very Good \\
3 & Predict & 76,49 & Good & 85,50 & Very Good \\
4 & Conclude & 74,62 & Good & 81,88 & Very Good \\
5 & Communicate & 67,91 & Good & 78,62 & Good \\
\hline
\end{tabular}

Most structured inquiry science skill indicators get well categorized average, while for guided science process skills most indicators get a very good category average. This suggests 
that inquiry learning is structured and guided can make students' science process skills good. To see the improvement of the science process skills, the following presented the scientific attitudes of each meeting in table 6.

Table 6. Results of Science Process Skills of Structured s and Guided Inquiry Classes by Each Meeting

\begin{tabular}{cccccccc}
\hline & & \multicolumn{6}{c}{ Science Process Skills } \\
\cline { 3 - 8 } No & Classes & \multicolumn{5}{c}{ Average of Meetings (\%) } \\
\cline { 3 - 8 } & & $\mathbf{1}$ & $\mathbf{2}$ & $\mathbf{3}$ & $\mathbf{4}$ & $\mathbf{5}$ & $\mathbf{6}$ \\
\hline 1 & Structured Inquiry & 47,98 & 53,58 & 56,94 & 63,43 & 70,07 & 76,19 \\
2 & Guided Inquiry & 48,18 & 58,04 & 60,50 & 67,89 & 73,18 & 82,17 \\
\hline
\end{tabular}

Based on the data in the table above, students' science process skills have improved at each meeting. students' science process skills in structured and guided inquiry classes each have significant improvements. This is because the activities in inquiry are embedded with steps that must use the skills of the science process, inquiry provides more opportunities for students to seek and find their own facts, concepts and principles through direct experience so that the learning process becomes more optimal (Rizal, 2014). Students no longer sit listening to the material or explanation from the teacher, but the students are directly involved in the learning process they can develop the skills they have.

This is supported by Hartati et. al learning model $5 \mathrm{E}$ learning cycle and structured inquiry have the same potential in improving the science process skills and students' cognitive learning outcomes (Hartati, T. A. W., Corebima, A. D., \& Suwono, 2015). This is in line with the study of Maikristina et. al that the skills of students' science processes that are learned using guided inquiry learning models have better achievement than students who are taught using problem solving model (Maikristina, N., Dasna, I. W., \& Sulistina, 2013).

For gain analysis of science process skill of structured and guided class students used the average value of students' science process skill at the first and sixth meeting, the skill of structured inquiry class science process gets gain 0,54 ; while the inquiry science skills of the inquiry student class gain a gain of 0.67 . From each experimental class the gain is in the moderate category. There is difference of result of learning skill of inquiry study of structured and guided inquiry, the following is presented difference test result using independent samples t-test in table 7. 
Tabel 7. Differentiated Test Science Process Skills of Structured and Guided Inquiry Classes

Independent Samples Test

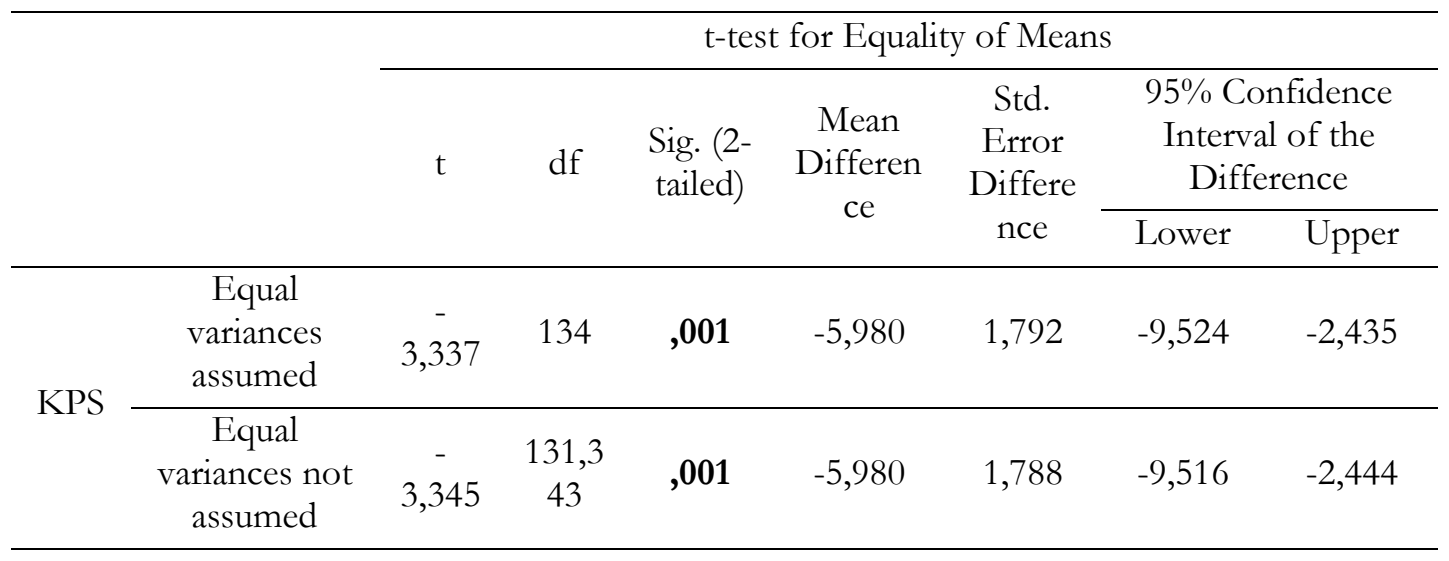

Based on the above table, the data of science process skill gained significance level 0,001 $<0,05$. This shows that there is a difference in the science process skill between structured and guided inquiry classes. This is caused because in guided inquiry class, the students are more stimulated to think in determining the research procedure independently, determining the variable, and formulating the hypothesis (Rahayu, 2016). These activities can increase students' enthusiasm and skills in carrying out activities so that students are accustomed to making science learning easier, actively learning, using a sense of responsibility in their own learning, improving learning decisions, and teaching research methods. Whereas in structured inquiry classes students conduct investigations through procedures established by teachers (Bell, R. L., Smetana, L., \& Binns, 2005), so that students feel constrained by existing procedures that make students less optimal in enhancing their enthusiasm and skill in trial activities.

This is in line with Sudaryanti's study which states that there are significant differences in science process skills between classes using structured inquiry approaches and classes using guided inquiry (Sudaryanti, 2015). Rahayu states that there is a significant difference between the effectiveness of learning with guided inquiry approach and structured inquiry to the students' scientific skill ability (Rahayu, 2016). Based on the gain test and the independent sample t-test above, it can be concluded that structured and guided inquiry learning models can improve students' science process skills but have different improvements. Learning with inquiry is better guided in improving the science process skills than structured inquiry.

\section{CONCLUSION}

The conclusions from the analysis and discussion result that the structured and guided inquiry learning model can improve the mastery of the concept, the scientific attitude, and the 
science process skill of the students but have different improvements. The inquiry learning model is better guided in enhancing the mastery of concepts, scientific attitudes, and students' science process skills compared to guided inquiry learning models.

\section{REFERENCES}

Aceska, N. (2016). New Science Curriculum Based on Inquiry Based Learning- A Model of Modern Educational System in Republic of Macedonia. Journal of Education in Science, Environment and Health (JESEH), 2(1), 1-12.

Aktamis, H., \& Ergin, O. (2008). The effect of scientific process skills education on students' scientific creativity, science attitudes and academic achievementNo Title. Asia-Pacific Forum on Science Learning and Teaching., 9(1), 1-21.

Bayram, Z., Oskay, Ö. Ö., Erdem, E., Özgür, S. D., \& Şen, Ş. (2013). Effect of Inquiry Based Learning Method on Students' Motivation. Procedia-Social and Behavioral Sciences, 106, 988996.

Bell, R. L., Smetana, L., \& Binns, I. (2005). Simplifying Inquiry Instruction. The Science Teacher, 72(7), 30-33.

Bunterm, T., Lee, K., Ng Lan Kong, J., Srikoon, S., Vangpoomyai, P., Rattanavongsa, J., \& Rachahoon, G. (2014). Do different levels of inquiry lead to different learning outcomes? A comparison between guided and structured inquiry. International Journal of Science Education, 36(12), 1937-1959.

Development, U. S. A. for I. (2014). Buku Sumber untuk Dosen LPTK Pembelajaran IPA SMP di LPTK. USAID.

Dewi, N. L., Dantes, N., \& Sadia, I. W. (2013). Pengaruh model pembelajaran inkuiri terbimbing terhadap sikap ilmiah dan hasil belajar IPA. Jurnal Pendidikan Dasar, 3(1).

Ergul, R., Simsekli, Y., Calis, S., Ozdilek, Z., Gocmencelebi, S., \& Sanli, M. (2011). The effects of inquiry-based science teaching on elementary school students' science process skills and science attitudes. Bulgarian Journal of Science and Education Policy (BJSEP), 5(1), 48-68.

Hacieminoglu, E. (2016). Elementary School Students' Attitude toward Science and Related Variables. International Journal of Environmental and Science Education, 11(2), 35-52.

Hartati, T. A. W., Corebima, A. D., \& Suwono, H. (2015). Pengaruh Model Pembelajaran Inkuiri Terstruktur dan Siklus Belajar 5E terhadap Keterampilan Proses Sains dan Hasil Belajar Kognitif Siswa pada Kemampuan Akademik Berbeda. Jurnal Pendidikan Sains (JPS), 3(1), 22-30.

Hendracipta, N. (2016). Menumbuhkan Sikap Ilmiah Siswa Sekolah Dasar Melalui Pembelajaran IPA Berbasis Inkuiri. Jurnal Pendidikan Sekolah Dasar, 2(1), 109-116. 
Hermawati, N. W. M. (2012). Pengaruh model pembelajaran inkuiri terhadap penguasaan konsep biologi dan sikap ilmiah siswa SMA ditinjau dari minat belajar siswa. Jurnal Pendidikan IP A, 2(2), 1-30.

Khan A, S., Shah, A., Makhdoom, S., Mahmood, Z., \& Zareen, R. (2012). Scientific Attitude Development at Secondary School Level: A Comparison between Methods of Teaching. Language in India, 12(9), 439-454.

Kuhlthau, C. G. (2003). Rethinking Libraries for the Information Age School. Liblary Skill, 22(4), 3-5.

Maikristina, N., Dasna, I. W., \& Sulistina, O. (2013). Pengaruh penggunaan model pembelajaran inkuiri terbimbing terhadap hasil belajar dan keterampilan proses sains siswa kelas XI IPA SMAN 3 Malang pada materi hidrolisis garam. Jurnal Pembelajaran Kimia, 6(1), 98108.

Permendikbud. (2016). Lampiran Peraturan Menteri Pendidikan dan Kebudayaan Republik Indonesia Nomor 20 Tahun 2016 Tentang Standar Kompetensi Lulusan Pendidikan Dasar dan Menengah.

Praptiwi, L., Sarwi, \& Handayani, L. (2012). Efektivitas model pembelajaran eksperimen inkuiri terbimbing berbantuan my own dictionary untuk meningkatkan penguasaan konsep dan unjuk kerja siswa SMP RSBI. Unnes Science Education Journal, 1(2), 87-95.

Prasetyowati, E. N., \& Suyatno, S. (2016). Peningkatan Penguasaan Konsep Dan Keterampilan Berpikir Kritis Siswa Melalui Implementasi Model Pembelajaran Inkuiri Pada Materi Pokok Larutan Penyangga. Jurnal Kimia Dan Pendidikan Kimia, 1(1), 67-74.

Rahayu, N. (2016). Pengarub Pembelajaran dengan Pendekatan Guided Inquiry dan Structured Inquiry terhadap Kemampuan Penguasaan Konsep dan Scientific Skill Materi Sistem Pencernaan pada Siswa SMA Kelas XI IPA. Universitas Negeri Yogyakarta.

Rizal, M. (2014). Pengaruh Pembelajaran Inkuiri Terbimbing dengan Multi Representasi terhadap Keterampilan Proses Sains dan Penguasaan Konsep IPA Siswa SMP. Jurnal Pendidikan Sains, 2(3), 159-165.

Sanjaya. (2009). Strategi Pembelajaran Berorientasi Standar Proses Pendidikan. Kencana.

Şimşek, P., \& Kabapınar, F. (2010). The Effects of Inquiry-Based Learning on Elementary Students' Conceptual Understanding of Matter, Scientific Process Skills and Science Attitudes. Procedia-Social and Behavioral Sciences, 2(2), 1190-1194.

Sudaryanti. (2015). Komparasi Keefektifan Pendekatan Inkuiri Terbimbing dan Pendekatan Inkuiri Terstruktur terhadap Keterampilan Berpikir Kritis, Penguasaan Konsep dan Keterampilan Proses Sains Siswa. Program Pascasrjana Universitas Negeri Yogyakarta.

Suduc, A. M., Bizoi, M., \& Gorghiu, G. (2015). Inquiry Based Science Learning in Primary Education. Procedia-Social and Behavioral Sciences, 205, 474-479.

Susanto, A. (2012). Teori Belajar \& Pembelajaran di Sekolah Dasar. Prenada Media Grup. 